\title{
Mídia e direitos humanos: tensionamentos e problematizações em tempos de globalização neoliberal
}

\author{
Fábio Souza da Cruz \\ Universidade Católica de Pelotas (UCPel)
}

Mídia e direitos humanos: tensionamentos e problematizações em tempos de globalização neoliberal Resumo: Este artigo traz reflexões sobre algumas problemáticas envolvendo a mídia tradicional brasileira e a questão dos direitos humanos, no cenário da globalização neoliberal. Parte da abordagem dos dois elementos deste estudo na atualidade para apontar fatores que, agindo sobre eles, ajudam a moldar uma determinada conjuntura. Adotando uma postura crítica, histórica e dialética, faz uma intersecção entre os veículos brasileiros de comunicação de massa tradicionais e os direitos humanos, com o propósito de problematizar questões sobre ambos e apontar possíveis saídas. Como conclusão, não pretende generalizar resultados a partir da pesquisa bibliográfica utilizada, mas, sim, detectar tendências e possibilidades com base em uma amostra significativa de dados.

Palavras-chave: Mídia. Direitos humanos. Globalização neoliberal. Crítica. Responsabilidade social.

\section{Media and Human Rights: Tensions in Times of Neoliberal Globalization}

Abstract: This article reflects on issues involving the traditional Brazilian media and human rights in the scenery of neoliberal globalization. It looks at the two elements of this study to indicate factors that help to form a certain conjuncture. Adopting a critical, historic and dialectical position, it conducts an intersection between traditional Brazilian mass media outlets and human rights, to analyze questions about both and indicate possible options. The conclusion does not generalize based on bibliographic research used but detects trends and opportunities based on a significant sample of data.

Key words: Media. Human rights. Neoliberal globalization. Critical. Social responsibility. 


\section{Introdução}

Neste trabalho, traçaremos um mapeamento do papel da mídia tradicional brasileira e de questões atinentes aos direitos humanos (DH) na atualidade. Considerando isso, inicialmente, apresentaremos um breve perfil da globalização neoliberal - fio condutor deste estudo - e, na sequência, averiguaremos como os veículos de comunicação de massa produzem significado nesse cenário, procurando identificar quais são os elementos que influenciam suas construções. Para tanto, neste primeiro momento, adotaremos os pressupostos teórico-metodológicos de Douglas Kellner (1995, 2001).

Posteriormente, analisaremos os $\mathrm{DH}$, tendo como ponto de partida a visão que se inscreve no imaginário social nos dias de hoje e a a urgente necessidade de problematizar essa questão.Neste sentido, lançaremos mão do cabedal intelectual de Helio Gallardo (2000, 2006, 2008), Joaquín Herrera Flores (2005) e David Sánchez Rubio (2007, 2010), buscando mostrar e demonstrar os seus pontos de convergência.

Seguindo uma postura crítica, histórica e dialética, procuraremos promover uma intersecção entre a mídia - mais especificamente a tradicional brasileira - e os DH com o objetivo principal de problematizar o momento atual que envolve e permeia esses dois objetos para, na sequência, analisar e entender a concepção em voga sobre $\mathrm{DH}$ e a responsabilidade social dos veículos de comunicação massiva sobre esse tema. A partir disso, apontaremos possíveis alternativas, visando um cenário mais justo e igualitário, onde a mídia poderia exercer um novo papel, de extrema importância no que tange à questão dos DH. Salientamos que a presente investigação não pretende generalizar resultados, mas, sim, detectar tendências e vislumbrar possibilidades em um determinado contexto.

\section{A globalização neoliberal e o universo midiático: elementos para uma análise crítica}

A globalização traduz uma atmosfera comandada por empresas transnacionais - os chamados conglomerados econômicos-, pelo livre comércio e pelas privatizações. Na atual conjuntura, Estados Unidos, Japão e Europa Ocidental (principalmente a Alemanha) despontam como os principais nomes de força do processo, juntamente com as corporações transnacionais e organizações multilaterais. A partir deste cenário, o capitalismo global - ou neoliberalismo - agrava as contradições sociais em todos os setores e isso se dá mais fortemente "nos países dependentes, periféricos, atrasados, do terceiro mundo" (IANNI, 1995, p. 144).

Com a globalização, os produtos se desterritorializam. Ocorre, por conseguinte, uma descen- tralização da mão de obra humana. Consequentemente, há uma redução do emprego regular: os trabalhadores "perpétuos" são substituídos pelos temporários, informais, subcontratados, o que acaba ocasionando também o enfraquecimento dos sindicatos (HARVEY, 1992; MARTÍN-BARBERO, 2002). Esse cenário sugere uma imensa fábrica, a "fábrica global" de Ianni $(1995,1997)$. Nesta "fábrica", marcada pela flexibilidade, "a vida de trabalho está saturada de incertezas" (BAUMAN, 2001, p. 169), ou seja, ao contrário dos tempos de outrora, agora, a estabilidade dos empregados não é mais assegurada. Além disso, outros fatores se agravam com esse processo, tais como a falta de habitação, saúde e educação, a miséria, o narcotráfico e a violência em todas as suas formas (GARCÍA CANCLINI, 1995, 2011).

Em tal contexto, a arquitetura das cidades sofre mais um reflexo da globalização: ora "livre" e "solta", acaba cedendo lugar a uma nova realidade: a da "máxima" segurança, através das grades, de alarmes e de condomínios fechados (CRUZ, 2009). Na mesma linha de pensamento, constatamos que o aprofundamento das desigualdades sociais gerado pelo regime neoliberal também fortalece uma crescente imigração para os aparentes "polos de prosperidade do planeta", os Estados Unidos e a Europa Ocidental (RAMONET, 1998, p. 30), o que acarreta, por sua vez, outro resultado: as reações, por vezes extremistas, de movimentos nacionalistas, separatistas, xenófobos e neonazistas (MARTÍN-BARBERO, 1995; VIZENTINI, 1996).

Para Bauman (1999), com a globalização, o "tripé da soberania" (a autossuficiência militar, econômica e cultural) é afetado de maneira irreversível. A insuficiência militar é agravada frente às dificuldades sociais, como o desemprego, por exemplo, que corroboram, dentre outros fatores, o recrudescimento da violência e a insegurança, conforme tratado antes. Com relação ao aspecto cultural, a avalanche da indústria cultural, em todos os seus níveis e estilos, fomenta uma sociedade do consumo que é alimentada constantemente por produtos feitos sob medida e com curto tempo de duração e apreciação, conforme salienta García Canclini (1995). Já na área econômica, devido à pujança dos mercados financeiros globais, o Estado perde sua força, ficando reduzido ao âmbito político.

A partir desse cenário, definitivamente, hoje, os meios de comunicação de massa consistem no principal ou, na pior das hipóteses, em um dos principais agentes de mediação da sociedade em tempos de globalização. Através de textos, sons e imagens, a cultura midiática corrobora, assim, os laços sociais, ao mesmo tempo que fornece elementos de homogeneização de discursos e identidades.

Nesse sentido, a mídia tradicional brasileira constrói mitos e estereótipos, sugere regras, maneiras de 
pensar, modas e hábitos. Por trás deste véu sedutor, busca audiência e, consequentemente, lucros cada vez maiores. Para isso, lança mão de uma mistura de elementos oficiais com outros, nem sempre palatáveis como, por exemplo, o fait divers (informação sensacionalista).

Passando à frente de instituições como a família, a escola e a igreja, os meios de comunicação de massa, através dos seus veículos, adquirem caráter centralizador na atualidade. Nesta realidade, muitas vezes, atuam em compasso com as forças hegemônicas da sociedade. Considerando isso, percebemos que a ideologia transmitida neste caso "é (geralmente) a do branco masculino, ocidental, de classe média ou superior; são as posições que veem raças, classes, grupos e sexos diferentes dos seus como secundários, derivativos, inferiores e subservientes". Desta forma, a mídia acaba constituindose em um aparelho responsável pela promoção simbólica de uma nítida separação entre atores "dominantes/dominados e superiores/inferiores, produzindo hierarquias e classificações que servem aos interesses das forças e das elites do poder" (KELLNER, 2001, p. 83). Tal cenário implica lançar mão de teorias que deem conta da sua complexidade.

\subsection{Por uma teoria social crítica da mídia: o arcabouço teórico-metodológico de Douglas Kellner}

Levando em conta essa realidade, percebemos que a mídia tradicional brasileira consiste em uma espécie de palco por onde desfilam as mais diversas forças da sociedade. Neste sentido, os veículos de comunicação de massa reproduzem os embates entre os setores hegemônicos e contra-hegemônicos - ou de resistência. A partir disso, procurando estabelecer e verificar as ligações entre os atores envolvidos no campo social, Kellner (2001) se utiliza da articulação. Este conceito traduz, portanto, um ponto importante, ligado ao estudo do processo de organização e produção do discurso dos órgãos de comunicação massivos em um determinado contexto. Somente assim, através de um minucioso exercício de reconstrução histórica dos fatores em jogo, será possível refletirmos, interpretarmos e explicarmos criticamente as questões relativas à cultura midiática, suas relações com o todo social e suas produções.

Sabemos que toda e qualquer produção midiática pressupõe articulações de cunho interno. Assim, reconhecemos as visões de mundo da empresa de comunicação e do produtor de informação, ambas baseadas em contextos particulares. Respeitando determinadas regras e aspectos técnicos, consideramos, também, que um texto é constituído dentro de um gênero (televisivo, radiofônico, impresso etc.).

Além disso, as relações externas dos produtores de informação e das empresas em que trabalham, em maior ou menor grau, também interferem no produto final - a informação. Tudo isso consiste em um processo complexo. Desta forma, percebemos a importância dispensada às mediações e à contextualização dos fatos em uma atividade de investigação crítica, histórica e dialética. Este método facilita o entendimento dos desdobramentos.

Em um cenário em que a qualidade da informação é, muitas vezes, inversamente proporcional ao índice de audiência, o racional é, portanto, superado com certa frequência, pelos desvios discursivos, pelo espetáculo, pelo conflito, pela instauração do medo e pela fantasia das imagens. Através da mídia, vislumbra-se uma realidade na qual o discurso noticioso é substituído por uma espécie de "discurso publicitário", que tem a pretensão de homogeneizar identidades, estereotipado e mercadológico, a-histórico e sem aprofundamento. Por isso mesmo, é desprovido de elementos para a reflexão, ou seja, os meios ficam impossibilitados de justificar os fins (CRUZ; VARELA, 2009, on-line).

Ocorre, portanto, a primazia do "o quê" sobre o "como" e o "por quê", o que traduz um "discurso carente", superficial, e, muitas vezes, unilateral, que fere a ética jornalística, pois não contempla todos os lados envolvidos em determinada questão (CRUZ; VARELA, 2009, on-line). Neste sentido, Kellner (2001, p. 149) salienta que "se deve prestar atenção ao que fica fora dos textos ideológicos, pois frequentemente são as exclusões e os silêncios que revelam o projeto ideológico do texto."

A descontextualização dos fenômenos pode estabelecer, assim, a noção do inexplicável e sem sentido no imaginário social. Nessa direção, Lage (1998, p. 308) sustenta que "fatos que contrariam versões dominantes, de interesse do sistema de poder, podem ser desqualificados como fenômenos inexplicáveis".

Por conseguinte, vivenciamos na realidade midiática brasileira a cultura do efêmero; o triunfo do descartável. São veiculadas informações superficiais, com carência de substancialidade. É, portanto, neste cenário, que considerável parte dos veículos de comunicação de massa fomentam o pensamento rápido e miserável, pobre e acrítico, ao mesmo tempo que é sempre salutar lembrar - protegem determinadas forças da sociedade.

Por outro lado, essa observação provoca a seguinte constatação: em geral, a cultura da mídia estimula a dominação social lançando mão, por vezes, de um discurso que visa à marginalização e/ou banalização de certos temas e forças da sociedade, enfraquecendo-os. Entretanto, essa mesma cultura pode incentivar a resistência e a luta contra as classes hegemônicas ao utilizar uma linguagem mais isenta, menos comprometida com o poder. Ora conservadora, ora progressista, a mídia consiste, portanto, em um amontoado de contradições. 
Baseado nas premissas trabalhadas até aqui, Kellner $(1995,2001)$ propõe o que ele chama de "alfabetismo crítico" ou "pedagogia crítica da mídia". Tal perspectiva teórico-metodológica significa um novo olhar - crítico - sobre a mídia, o qual promoveria uma tonificação do receptor com relação às produções dessa.

Sustenta o autor que uma leitura crítica das produções oriundas dos veículos de comunicação de massa deve ser feita de forma política, o que refletirá o cenário de práticas e discursos da sociedade. Consequentemente, torna-se também imprescindível e ao mesmo tempo enriquecedor investigar, de maneira interdisciplinar, os sentidos que a cultura da mídia fabrica e, ainda, quais os movimentos contrahegemônicos que se dão sobre essas construções.

Considerando isso, ao estudar as produções midiáticas sob o prisma das relações entre ideologias, movimentos sociais e o contexto que as envolvem, inspirado pelo sociólogo Robert Wuthnow, Kellner (2001) lança mão de três categorias, a saber: horizonte social, campo discursivo e ação figural.

$\mathrm{O}$ horizonte social diz respeito às múltiplas relações, às práticas e experiências que se desenvolvem dentro do campo social, e que acabam, desta forma, por contextualizar o local, a época e o cenário em que se dá a produção da cultura da mídia. O campo discursivo contempla as mediações, onde estão presentes todos os elementos (incluindo, aqui, os atores hegemônicos e contra-hegemônicos, dominantes e dominados, superiores e inferiores) envolvidos no discurso dos veículos de comunicação de massa. Já a ação figural implica mostrar os desdobramentos sociais de acordo com o horizonte social e o campo discursivo (CRUZ, 2009, on-line).

Tendo em vista esse mapa analítico, nos estudos da cultura da mídia propostos por Kellner (2001), em uma determinada circunstância social e histórica, são analisados o modo de produção da informação, a mensagem propriamente dita, que é distribuída através de um canal, a recepção dessa pelos públicos também dentro de um contexto específico - e os efeitos do texto nesse público. Cabe ressaltar aqui que, no amplo e variado leque de opções que compõem o "menu" midiático, a questão dos DH, nosso próximo tópico, faz-se presente.

\section{As diferentes visões acerca dos $\mathrm{DH}$ e a emergência de um novo pensar na atualidade}

Na cultura ocidental, atualmente, constatamos que o imaginário vigente sobre DH é "insuficiente, bastante reduzido e demasiado estreito" (SÁNCHEZ RUBIO, 2007, p. 11). Na verdade, o que se instaura na sociedade é uma concepção simplificada dos $\mathrm{DH}$, entendimento este que não dá conta da complexidade do tema, pois liga-o somente a questões normativas e jurídicas e o concebe como um direito fundamental, um bem "natural", que recebemos ao nascer.

Nesse cenário, os direitos "naturais", considerados "absolutos" e encarados como "sagrados e invioláveis" (GALLARDO, 2006, p. 19), são reconhecidos pelo Estado, o que não necessariamente significa dizer que acolhem todos os seres humanos da face da terra. Já os chamados direitos "progressivos", de caráter econômico, cultural e social, são efetivados aleatoriamente e dependem da generosidade do mercado e do Estado, o que, diga-se de passagem, pode vir a constituir-se em mera ilusão.

Nessa mesma linha de pensamento, institui-se, também, uma ideia positivista - e cínica - de que as coisas estão como estão porque "assim é a vida". Eé justamente a partir desta postura de total descaso e conformidade, que uma minoria sai ganhando - com um claro ou velado consentimento do Estado - em detrimento de uma maioria desassistida.

Não obstante, os direitos individuais e políticos de primeira geração - "triunfam" muito mais do que os direitos igualitários "progressivos" - de segunda geração - e os regidos pela solidariedade, decorrentes da influência impactante das novas tecnologias - de terceira geração. Tal visão fortalece os anseios das forças hegemônicas da sociedade e, concomitantemente, enfraquece as outras duas gerações de $\mathrm{DH}$ promovendo uma (de)generação dos DH (SÁNCHEZ RUBIO, 2010).

Em face dessa realidade, para encararmos a questão dos DH "de frente", devemos reconhecer que o seu fundamento maior é de cunho político, o que significa considerar nesta discussão o contexto sóciohistórico, averiguando as relações sociais que se estabelecem. Esta forma - crítica - de (re)pensar os DH consiste na única possível para entender a temática.

Levando em conta esse novo olhar sobre os DH, no seu cerne, há uma disputa política - assimétrica extremamente complexa de forças (locais, regionais, nacionais e internacionais) hegemônicas e contrahegemônicas que lutam na tentativa de fazer vingar suas ideias e anseios. No entanto, essa concepção sócio-histórica de DH enfrenta visões distintas da sua - como a lei natural - e, concomitantemente, faz oposição à "suposição unilateral [...] de que um DH depende de seu reconhecimento constitucional ou jurídico" (GALLARDO, 2006, p. 8). Isto se deve pelo fato de que, na verdade, os DH são determinados por lutas sociais particulares que precedem reconhecimentos jurídicos. Conforme Gallardo (2008, p. 5),

A concepção sócio-histórica indica que o fundamento de DH está em outro mundo possível, derivado das lutas das diversas sociedades civis emergentes modernas, e na capacidade destas lutas para conseguir a judicialização de suas demandas e a incorporação de sua sensibilidade específi- 
ca ou peculiar na cultura reinante e na cotidianidade que se segue dela e que potencia sua reprodução.

Vale salientar, aqui, que temos clara a importância das Declarações de Direitos e, inclusive, das leituras tradicionais, entretanto, insistimos na sua insuficiência e nos seus aspectos paradoxais insuperáveis. Neste sentido, ratificamos que

[...] a mera judicialização de direitos esquece que as normas jurídicas e os tribunais constituem um subsistema do corpo político e que, por isso, resultam débeis ou forçosamente limitados ante a 'razão do Estado' que se orienta a reproduzir assimetrias como condição de uma dominação (econômica-social e cultural) que supõe e produz discriminações (GALLARDO, 2000, p. 39).

Dessa maneira, considerando o que foi exposto até o momento e mantendo-nos fieis a uma abordagem crítica dos $\mathrm{DH}$, cremos que as formas de dominação/tirania que se abatem de forma especial sobre as vítimas dos países "eufemisticamente" chamados de "nações em desenvolvimento" reforçam sobremaneira a exigência de um (re)pensar das balizas abstracionistas e idealizadoras de compreensão dos direitos humanos. Para isso, acreditamos que as reflexões que giram em torno desta temática não podem ser realizadas de maneira dissociada do fenômeno da globalização e da sua nova fase, a neoliberal.

\section{1 (Re)pensando os direitos humanos no mundo globalizado}

Para identificar alguns motivos pelos quais os DH não se cumprem em grande parte do planeta Terra nos tempos atuais, lançamos mão de Herrera Flores (2005, p. 21, esclarecimentos do autor). Segundo este autor, podemos listar:

[...] a falta de vontade dos governos representados na Assembleia Geral da ONU (Organização das Nações Unidas) [...] [e, também, o] contexto de relações sociais dominado pela força econômica dominante no sistema mundial [que] tem impedido sua real e concreta colocação em prática.

Esse cenário é alimentado pelo discurso falacioso de que a política, assim como outras áreas, chegou ao fim. Esta fala vai ao encontro dos objetivos das forças hegemônicas da sociedade, que têm o intuito de manter e eternizar a assimétrica situação atual.

Nessa mesma linha de raciocínio, os critérios naturais dominam a sensibilidade cultural sobre DH nos dias de hoje. Na verdade, essa visão de DH nada mais representa do que obrigações "sob a forma de responsabilidades" (GALLARDO, 2006, p. 26). Não reconhecendo o aspecto conflitivo das relações humanas, tal concepção entende os DH como uma derivação da natureza humana. Nascem com todo e qualquer cidadão. Não obstante, esta versão moderna de direito natural teve grande contribuição de John Locke, que concebia os "seres humanos [como pessoas que] nascem iguais (universalidade), racionais, livres (com vontade) e proprietários (porque conseguem suas riquezas mediante seu trabalho)" (GALLARDO, 2006, p. 29).

No entanto, devemos fugir dessas armadilhas e buscar uma reflexão teórica crítica dos $\mathrm{DH}$ que expanda o presente, com o dever de "fazer visível o visível" (HERRERA FLORES, 2005, p. 41).

Precisamos levar em conta contextos específicos, não universalistas, que não se resumam e sejam resolvidos somente pela instância jurídica, mas que possibilitem discernir e vislumbrar ações em torno de uma realidade universal, verdadeiramente melhor e mais justa, de inclusão, para aqueles que dela necessitam e clamam por ela.

Na prática, sabemos que a questão em torno dos DH fica reduzida, conforme colocado anteriormente, aos interesses de forças hegemônicas da sociedade. E são justamente estes agentes sociais que promovem a exclusão dos chamados populares, ou seja, dos blocos vulneráveis como, por exemplo, os pobres e os trabalhadores dos setores rurais (GALLARDO, 2006). Princípio da injustiça, a exclusão pressupõe, assim, admitir um não pertencimento a um grupo civil que pertence a uma determinada comunidade (VILLORO, 2000).

É verossímil dizer que, desde as ideologias naturais sobre os $\mathrm{DH}$, foram criadas categorias de não pessoas, "ou seja, indivíduos, setores sociais ou povos e culturas que carecem desses direitos e de todo direito" (GALLARDO, 2006, p. 7) e que são tratados como meras "distorções de mercado". Sendo assim, agora, os "anormais", que insistem em resistir, deverão ser aniquilados. Isso gera um verdadeiro "terrorismo de Estado", de onde são criados cenários que visam favorecer a manutenção da ideologia neoliberal da globalização (HINKELAMMERT, 2005).

Infelizmente, percebemos que essa realidade está longe de desaparecer devido ao atual contexto sócio-histórico trabalhado aqui. No entanto, é urgente promover mudanças, e estas obrigatoriamente implicam em alterações na atual economia, pois, sem isso, a sobrevivência da própria humanidade ficaria ameaçada. Esse cenário, de notável assimetria social, projeta novas discussões. A negação do "padrão de normalidade" da justiça e a consequente exclusão como injustiça fazem emergir "um novo sujeito moral", que fará frente ao sujeito "normal" e que projetará "um novo modelo de justiça" (VILLORO, 2000, p. 111), mais justo e igualitário, modelo este que pode e deve ser universalizado. 


\section{Em busca da problematização possível}

Inicialmente, vamos visualizar o cenário de nossa investigação. Ele diz o seguinte: a engrenagem está funcionando. A roda está girando. Tudo conspira a favor: em boa parte da realidade midiática brasileira, a complexidade do tema dos DH é reduzida às questões normativo-jurídicas e naturais, simplificação esta que fortalece os anseios particulares das forças hegemônicas da sociedade. Os excluídos, cada vez mais isolados e enfraquecidos, estão à margem do processo, e os agentes sociais hegemônicos triunfam exitosamente. Além disso, o imaginário popular é permeado pelo "exemplar" argumento de que "assim é o mundo" (GALLARDO, 2006, p. 21).

E o mundo é assim: o cenário é competitivo e altamente discriminatório. Diferenças de gênero, classe, raça etc., muitas vezes, não são respeitadas. Nesta realidade, são as forças hegemônicas que decidem quem está dentro e quem está descartado do jogo. Quem não se encaixar no sistema estará fora e entregue à própria sorte. Consequentemente, aumentam a fome e a miséria. Recrudesce a violência. Instaura-se a crise.

Garantias fundamentais não são criadas e/ou reguladas pelos Estados e pelas organizações como a ONU e a Organização dos Estados Americanos (OEA) e, assim, os menos favorecidos ficam à mercê dos interesses por vezes escusos das forças hegemônicas da sociedade. Em suma, estamos convencidos de que a lógica do regime neoliberal globalizante e a dos excluídos são incongruentes. É assim o mundo? Sim, assim é o mundo. Ou, se preferirmos dizer, assim está sendo o mundo.

Entretanto, podemos inverter a lógica tecendo o seguinte questionamento: assim deve ser o mundo? A resposta natural para esta indagação seria o não, o que levaria a um novo pensar do mundo. Neste, o "diferente" teria as suas diferenças respeitadas e a sua tão requerida participação "no aspecto concreto da vida social ou política de que foi excluído" (VILLORO, 2000, p. 113) seria finalmente atendida.

É a partir dessa lógica que devemos analisar o contexto. E será com esse sentimento de mudança que olharemos para frente em busca de um horizonte mais iluminado, mais solidário, fraterno e pacífico, enfim, mais humano. Assim, é necessário percebermos a questão dos DH levando em conta suas "tramas sociais", onde, em um verdadeiro jogo político, extremamente complexo, forças sociais hegemônicas e contra-hegemônicas atuam e que, em muitas vezes, "as múltiplas tribunas do poder se excedem provocando situações de exclusão, marginalização e discriminação"'(SÁNCHEZ RUBIO, 2007, p. 16).

Portanto, (re)pensar DH consiste, hoje, em tarefa necessária e urgente no atual e "intolerável" contexto globalizante. Não há mais tempo a perder. É preciso lutar pelo bem comum. É preciso lutar pela dignidade humana. É preciso antecipar o futuro, resgatá-lo e entregá-lo curado. E isto, obrigatoriamente, deve ser encarado como a "reação cultural mais importante que podemos levar a cabo (e que acarretará) o processo de humanização do humano", o que significa, portanto, resistir "às debilidades e passividades que marcam os planos de transcendência (seja Deus, seja a Razão, seja a História, seja o Mercado...)" (HERRERA FLORES, 2005, p. 44-45).

Expostos o horizonte social e o campo discursivo da nossa investigação, voltemos, agora, nossas atenções para os veículos de comunicação de massa e o seu (eloquente) papel no mundo globalizado e, consequentemente, na questão dos $\mathrm{DH}$, com vistas a detectar a ação figural. Outrossim, sabemos que a mídia tradicional brasileira consiste em peça fundamental para a "consolidação das democracias [...] [e do] desenvolvimento de todas as nações adeptas, ao menos formalmente, deste regime" (CANELA, 2008, p. 11, esclarecimentos do autor).

Cientes disso, de acordo com Canela (2008, p. 11), percebemos que os veículos de comunicação massiva deveriam exercer (pelo menos) três funções. Numa primeira, a de contribuir "para o agendamento dos temas prioritários para o desenvolvimento humano", os DH seriam abrangidos. Entretanto, essa inclusão não poderia se dar somente quando algo de "espetacular" acontecesse. A segunda tarefa dos media seria a de adquirir um papel central no sentido de colaborar para que os governos, instituições privadas e a sociedade civil também sejam mais responsáveis pela "formulação, execução, monitoramento e avaliação das políticas públicas", o que proporcionaria uma maior integração dessas forças. Por fim, informar, "de maneira contextualizada, os cidadãos e as cidadãs de tal forma que estes possam participar mais ativamente da vida política, fiscalizando e cobrando a promoção de todos os direitos humanos" (CANELA, 2008, p. 12). Ou seja: quanto mais esclarecidos forem os membros da sociedade civil, melhores condições terão de exercer os seus direitos de cidadãos.

E é justamente essa última função dos media que será explorada aqui com o objetivo claro de detectar a ação figural nas nossas análises. Não basta somente contemplar a temática dos DH em sua agenda diária. Os veículos de comunicação de massa tradicionais brasileiros necessitariam ir muito além disso. Para cumprirem com o seu dever de servir a sociedade de forma realmente esclarecedora e ética, embora este termo pareça um corpo cada vez mais estranho na atual conjuntura global, esses deveriam problematizar a questão dos DH.

Problematizar consiste em reconstruir historicamente os cenários para que possamos entender as suas práticas. Significa detectar qual é a lógica vigente, quais são os atores envolvidos no processo e de que forma se dão as suas relações. Porém, não é isso o que per- 
cebemos em boa parte da cobertura dos veículos de comunicação de massa no Brasil. Neste sentido, geralmente, detectamos que a mídia utiliza uma noção simplificadora dos DH lançando mão de uma visão universal racionalmente formal, libertando a problemática dos DH do seu histórico impuro e injusto.

Vimos anteriormente que o discurso - naturalizado na sociedade - da universalidade dos DH é, na verdade, excludente, não passando, assim, de uma manobra dos setores hegemônicos visando à manutenção das assimetrias sociais. Não obstante, percebemos que, além de tratar os DH superficialmente, a mídia tradicional brasileira amplifica essa noção natural dos DH. Além disso, muitas vezes, ela descontextualiza o tema omitindo informações importantes em suas produções. Assim, constatamos que, ao ocultar as causas reais das desigualdades, os veículos de comunicação de massa prestam um desserviço à sociedade e, ao mesmo tempo, sustentam a expansão irrestrita de acumulação de capital em tempos de globalização, orientada pela agenda neoliberal, universalizando todo um fundamento éticopolítico liberal e individualista.

Ao que parece, os veículos brasileiros de comunicação massiva não estariam cumprindo com a sua verdadeira tarefa que é a de informar de forma ética e democrática a sociedade. Ao agirem desta maneira, assemelham-se à figura de um médico insano, que sai da sua casa para trabalhar e, ao chegar ao hospital, esquece que a sua função principal é a de salvar vidas.

Uma vez agendada uma pauta importante como a questão dos DH, esta deverá ser problematizada e também fiscalizada pela mídia. Entretanto, percebemos que este tratamento geralmente inexiste. Neste sentido, ter responsabilidade social no ato de informar não significaria engajar-se nos movimentos sociais levantando a bandeira de suas causas e fazendo um trabalho panfletário. Tampouco significa manter-se ao lado das forças hegemônicas da sociedade. Significa trânsito e conduta livres. Livres de qualquer força (agente/ator) social. Condutas livres e objetivas, pois o que está em jogo é o serviço prestado ao cidadão.

Tal cenário fomenta uma discussão sobre o papel dos produtores da informação. Pensemos no contexto particular de um profissional da comunicação. Ele possui uma determinada visão de mundo, o que lhe confere um olhar particular sobre as coisas. Este "lugar de fala" é tensionado com a visão de mundo da empresa na qual ele - o comunicador - trabalha. Neste sentido, portanto, temos que levar em conta inúmeros fatores que estão presentes na hora de produzir uma informação, a saber: o preparo (ou despreparo) do profissional com relação ao assunto que ele abordará, o grau de afinidade da empresa com os atores envolvidos na notícia e as pressões internas - dos superiores dentro da própria empresa em que o comunicador atua - e as externas - do poder e dos demais atores hegemônicos da sociedade como, por exemplo, os patrocinadores.

Não é segredo para ninguém que, hoje, impulsionadas pela aceleração desenfreada das novas tecnologias de informação e comunicação (NTIC), as grandes empresas de comunicação multiplicaram consideravelmente seus resultados reais e potenciais. Nesse bojo, surge a preocupação com relação à influência perniciosa que, por ventura, os veículos de comunicação possam exercer. Neste sentido, até mesmo os mais esclarecidos poderão acabar sucumbindo a isso, tamanha é a deturpação dos fatos do nosso dia-a-dia.

Ancoradas pelas NTIC, parte da mídia "despeja" diariamente uma série de técnicas com um certeiro objetivo: manter ou instaurar situações que beneficiem os setores hegemônicos da sociedade. O motivo é um só: em tempos de globalização, nada mais salutar do que se manter de braços dados com o poder e, neste caso específico, o poder reinante é o mercado.

No Brasil, grande parte dos veículos de comunicação massiva são órgãos a serviço de uma ideologia: a neoliberal. São empresas que servem como caixa de ressonância das forças hegemônicas. Para isso, produzem diariamente informações padronizadas recheadas de elementos sensacionalistas, carregadas de estereótipos e preconceitos de todo tipo, desvios, omissões e unilateralidades discursivos.

Descontextualizando e simplificando questões complexas como a dos $\mathrm{DH}$, a mídia tradicional brasileira estupra a inteligência do receptor, este o principal alvo, o elemento que deverá ser persuadido. Em tempos de globalização neoliberal, significativa parte dos veículos de comunicação produz cenários convenientes do presente e do futuro (LAGE, 1998) mantendo, assim, a ideologia vigente através do poder simbólico. Quando agem desta forma, a ética fica aborrecida.

Autênticas personificações do médico insano, os media tradicionais brasileiros ferem a ética em nome do mercado. Retiram da pauta ou tratam de forma manipulativa questões fundamentais como os DH. Seja 
por falta de preparo de seus profissionais, seja porque é movida por interesses particulares, atrelados ao poder, considerável parcela dos veículos de comunicação desinforma, ao invés de informar e, assim, contribui para deixar a estrada livre para o reinado do neoliberalismo em nível global.

\section{Considerações finais}

Ler criticamente os DH significa problematizar, estabelecer relações, questionar a realidade em busca de soluções plausíveis para o problema. Outrossim, cremos que estas surgirão a partir de ações dos novos movimentos sociais. Com o Estado debilitado, caberá a esses grupos tomar as rédeas da situação unindo forças, também, com os demais setores da sociedade interessados em inverter a rota desse neoliberalismo voraz e insaciável.

Através deste "novo sujeito moral”, quiçá vivenciemos um novo momento, infinitas vezes mais justo e igualitário, diversificado e, ao mesmo tempo, equilibrado. Momento este em que os DH sejam finalmente enfrentados com a devida seriedade que lhes é inerente.

Por sua vez, a mídia tradicional brasileira deveria mostrar a sua outra face. Uma face realmente comprometida com a sociedade, mais verdadeira, mais progressista e democrática. Que contextualize e problematize a complexa questão dos $\mathrm{DH}$ no cenário neoliberal global. Que olhe de frente - e com os olhos bem abertos - o jogo político de forças antagônicas que envolvem o tema e que questione a realidade "visível" e sabidamente cruel dos DH. Chega dos "discursos carentes"; chega dos "discursos publicitários"; chega da "síndrome do médico insano". É preciso dar um basta nisso. Dar um basta e arrumar o presente para preparar um futuro melhor.

Dar voz e vez aos "não pessoas" não significa panfletagem pró-excluídos, tampouco estamos, aqui, abandonando o caráter sério e criterioso de uma investigação científica. Dar voz e vez às minorias, aos grupos sociais que lutam por uma vida mais digna, consiste em lançar mão de uma bilateralidade discursiva, em dispensar espaços iguais tanto aos "normais" quanto aos "anormais", os "diferentes". Agir desta maneira denotará uma preocupação com a sociedade civil. Demonstrará que a mídia tradicional brasileira é livre para exercer a sua real função: informar ética e democraticamente a sociedade.

Os veículos de comunicação massiva brasileiros necessitam, portanto, informar sem discriminar e, também, sem ignorar a discussão de fundo relativa aos DH, a de que todo e qualquer cidadão tem direito à sua existência e ao seu desenvolvimento e a utilizar as mais variadas estratégias com a finalidade de alcançar os bens que asseguram a dignidade. $\mathrm{E}$ ao fazer isso, vale ressaltar mais uma vez, a mídia deve ser profunda, deve problematizar à exaustão a temática. Não há mais espaço para o superficial. Não há mais espaço para a banalização de questões sérias. Não há mais espaço para a simplificação de assuntos complexos.

Que esses veículos de comunicação de massa sejam a caixa de ressonância da sociedade brasileira e façam a ética sorrir. Que eles andem de braços e mãos dadas com ela. Que declarem todo o seu amor por e somente para ela. Sabemos que só isso não será o suficiente para reverter o perverso cenário atual. No entanto, devido ao incontestável poder que os media exercem hoje sobre as pessoas, essa mudança de postura poderá trazer avanços significativos e, quiçá, sem volta para as questões referentes aos DH. Conforme foi colocado anteriormente, é necessário agir. É preciso realmente enxergar o presente e, assim, preparar um cenário saudável para todos: os "normais" de agora e os "normais" do futuro.

\section{Referências}

BAUMAN, Z. Globalização: as consequências humanas. Rio de Janeiro: Jorge Zahar, 1999.

\section{1. \\ Modernidade líquida. Rio de Janeiro: Jorge Zahar,}

CANELA, G. A cobertura jornalística das políticas públicas sociais: elementos para debate. In:

Políticas públicas sociais e os desafios para o jornalismo. São Paulo: Cortez, 2008, p. 10-30.

CRUZ, F. S. da; VARELA, R. As políticas públicas para o MST na pauta da mídia tradicional brasileira: o cenário atual e elementos para reflexão. Razón y Palabra, n. 70, 2009. Disponível em: 〈http://www.razonypalabra.org.mx/ N/N70/Varela revisado.pdf $>$. Acesso em: 10 nov. 2010.

CRUZ, F. S. da. O processo de globalização no século XXI: um novo tempo de batalhas para o MST. 2009. Disponível em: <http://www.bocc.uff.br/pag/bocc-cruzprocesso-globalizacao.pdf $>$. Acesso em: 15 nov. 2010.

A cultura da mídia no Rio Grande do Sul: o caso MST e Jornal do Almoço. Razón Y Palabra, n. 72, 2010. Disponível em: <http://www.razonypalabra.org.mx/N/N72/ Varia 72/37 Souza 72.pdf >. Acesso em: 12 dez 2010.

GALlARDO, H. Política e transformación social. Discusión sobre derechos humanos. Quito: Serraj, 2000.

Derechos humanos como movimiento social. Bogotá: Desde Abajo, 2006. 
Teoría crítica: matriz y posibilidad de derechos humanos. Murcia: David Sánchez Rubio Editor, 2008.

GARCÍA CANCLINI, N. Consumidores e cidadãos. Conflitos multiculturais da globalização. Rio de Janeiro: UFRJ, 1995.

La globalización en pedazos: integración y rupturas en la comunicación. Disponível em: <http:// www.felafacs.org/dialogos-51>. Acesso em: 23 jan. 2011.

HARVEY, D. A condição pós-moderna. Tradução de Adail Ubirajara Sobral. São Paulo: Loyola, 1992.

HERRERA FLORES. J. Los derechos humanos como productos culturales. Crítica del humanismo abstracto. Navarra: IPES, 2005.

HINKELAMMERT, F. La transformación del Estado de Derecho bajo el impacto de la estratégia de globalización. Santiago do Chile, 2005. Disponível em: <http://www.revistapolis.cl/10/hinke.htm>.Acesso em: 15 nov. 2010.

IANNI, O. A sociedade global. Rio de Janeiro: Civilização Brasileira, 1995.

Teorias da globalização. Rio de Janeiro: Civilização Brasileira, 1997.

KELLNER, D. Lendo imagens criticamente: em direção a uma pedagogia pós-moderna. In: SILVA, T. T. da. Alienígenas na sala de aula - uma introdução aos estudos culturais em educação. Petrópolis: Vozes, 1995, p. 19-35.

A cultura da mídia. São Paulo: Edusc, 2001.

LAGE, N. Controle da opinião pública: um ensaio sobre a verdade conveniente. Petrópolis: Vozes, 1998.

MARTÍN-BARBERO, J. América Latina e os anos recentes: o estudo da recepção em comunicação social. In: SOUZA, M. W. de (Org.). Sujeito, o lado oculto do receptor. São Paulo: Brasiliense, 1995, p. 39-68.

Desencuentros de la socialidad y reencantamientos de la identidad. 2002. Disponível em: $<\underline{\mathrm{http}}$ // /www.comminit.com/en/node/150300/37>. Acesso em: 31 jan. 2011.

RAMONET, I. Geopolítica do caos. Petrópolis: Vozes, 1998.

SÁNCHEZ RUBIO, D. Repensar derechos humanos. De la anestesia a la sinestesia. Sevilla: Editorial MAD, 2007.
Sobre el concepto de "historización" y una crítica a la visión sobre las (de)generaciones de derechos humanos. In: FRUTOS, J.A. S. de; GALIANA, J. M. Ignacio Ellacuría 20 años después. Sevilha: Instituto Andaluz de Administración Pública, 2010, p. 42-51.

VILLORO, L. Sobre el principio de la injusticia: la exclusión (VIII Conferencias Aranguren, 1999). Revista Isegoría. Madrid: Instituto de Filosofia, v. 7, n. 22, p. 103-142, set. 2000.

VIZENTINI, P. G. F. A nova ordem global: relações internacionais do século 20 - quarta parte. Porto Alegre: Edit. Ufrgs, 1996.

\section{Fábio Souza da Cruz}

fabiosouzadacruz@gmail.com

Pós-doutor em Direitos Humanos, Mídia e Movimentos Sociais, Universidad Pablo de Olavide, Sevilha

Doutor em Cultura Midiática e Tecnologias do Imaginário pela Pontíficia Universidade Católica do Rio Grande do Sul (PUC-RS)

Professor na Universidade Católica de Pelotas (Ucpel)

\section{Ucpel - Programa de Pós-Graduação em Políti-} ca Social

Rua Félix da Cunha, 412

Centro

Pelotas - Rio Grande do Sul

CEP: 96010-000 